\title{
Ocena wpływu cieczy przemywających na jakość zacementowania rur w otworze wiertniczym po użyciu płuczki glikolowo-potasowej
}

\begin{abstract}
W artykule przedstawiono wyniki badań laboratoryjnych nad sformułowaniem składu cieczy przemywających pozwalających uzyskać wysoką jakość zacementowania kolumn rur okładzinowych po stosowaniu przy wierceniu płuczki glikolowo-potasowej. W toku badań sprawdzono wpływ pięciu rodzajów cieczy przemywających oraz wody na wartość przyczepności na kontakcie stwardniały zaczyn cementowy-skała. Zacementowane próbki rdzeni skalnych były sezonowane w temperaturze $20^{\circ} \mathrm{C}$ oraz $80^{\circ} \mathrm{C}$ przez okres dwóch i siedmiu dni, a następnie wyniki badania przyczepności odnoszono do przyczepności bazowej. Po analizie uzyskanych rezultatów wytypowano środki, których użycie zapewnia najwyższą efektywność usuwania osadu wytworzonego przez płuczkę wiertniczą.
\end{abstract}

Słowa kluczowe: płuczka glikolowo-potasowa, ciecz przemywająca, cementowanie, ekshalacje gazu.

\section{The impact of wash fluids on the quality of casing cementing after using glycol based drilling mud}

\begin{abstract}
The article presents results of laboratory tests, on the formulation of wash fluids composition, which allow to obtain high quality casing cementing after using glycol based drilling mud. During the studies the impact of five types of wash fluids, on the value of adhesion between set cement slurry and rock was tested. Cemented rock cores were kept at $20^{\circ} \mathrm{C}$ and $80^{\circ} \mathrm{C}$ for a period of two and seven days, and then the adhesion test results were compared to the base adhesion. After analysis of the obtained results, several agents were selected, the use of which provides the highest efficiency in the removal of mud cake created by the drilling fluid.
\end{abstract}

Key words: glycol based drilling mud, wash fluid, cementing, gas migration.

\section{Wprowadzenie}

Spośród wszystkich operacji wykonywanych w czasie wiercenia otworów wydobywczych (ropy lub gazu) rurowanie i cementowanie przestrzeni pierścieniowej należą do najbardziej istotnych działań. Trwałość i efektywność wydobycia zależą w bardzo dużym stopniu od sukcesu tego etapu. Jednym z najważniejszych wymogów stawianych przed zabiegiem cementowania kolumn rur okładzinowych jest to, aby stwardniały zaczyn cementowy tworzył maksymalnie szczelne i trwałe połączenie między rurami a skałą. Mimo dużego postępu w technice cementowania i coraz bardziej nowoczesnych składów stosowanych zaczynów cementowych ciągle zdarzają się nieuda- ne zabiegi. Sytuacje takie występują głównie w utworach ilastych i zailonych [4, 7].

Przy przewiercaniu warstw ilasto-łupkowych stosuje się płuczki wiertnicze inhibitowane, co oznacza, że wykazują one zdolność przeciwdziałania dyspersji i pęcznieniu materiałów ilastych. Obecnie wykorzystuje się głównie płuczki polimerowo-potasowe i glikolowo-potasowe, różniące się mechanizmami inhibitowania hydratacji skał ilasto-łupkowych, wynikającymi z właściwości fizykochemicznych zastosowanych inhibitorów polimerowych. Badania wykonane do tej pory wskazują, że płuczka glikolowo-potasowa skuteczniej zapobiega zjawisku hydratacji i dyspersji w trakcie 
wiercenia. Niestety prowadzone w otworach wiertniczych pomiary geofizyczne wykazują gorszą niż w przypadku płuczek polimerowo-potasowych jakość zacementowania. Prawdopodobną przyczyną takiego stanu rzeczy jest spo- sób, w jaki płuczka glikolowo-potasowa oddziałuje na ścianę otworu. Glikol w postaci hydrofobowej adsorbuje się na ścianie otworu, tworząc warstwę o ograniczonej rozpuszczalności w wodzie.

\section{Ekshalacje gazu - jeden ze skutków złej jakości zacementowania}

Jednym z największych problemów będących konsekwencją złej jakości zacementowania rur w otworze wiertniczym są pozarurowe migracje gazu ziemnego, mające wpływ na bezpieczeństwo, ochronę środowiska i przepisy prawne. Problem migracji ze szczególną częstotliwością występuje w rejonie przedgórza Karpat.

Analiza danych z lat 1997-2004 wykazała, że spośród 113 otworów odwierconych w tym okresie w regionie przedgórza Karpat w aż 33 odnotowano migrację gazu. Uważa się, że czynnikiem, który sprzyja migracjom gazowym, jest powstawanie mikroszczeliny na kontakcie kamień cementowy-rura okładzinowa oraz kamień cementowy-skała. Zjawiska termiczne towarzyszące procesom wiązania cementu, tj. wydzielanie dużej ilości energii cieplnej, powodują zmianę wymiarów kolumny rur okładzinowych (rozszerzalność), co w konsekwencji przyczynia się do powstania mikroszczeliny. Kolejnym czynnikiem sprzyjającym tworzeniu się mikroszczelin są występujące na ścianie otworu oraz na rurach osady płuczkowe. Oblepianie ściany otworu oraz rur okładzinowych płuczką może być przyczyną słabszego wiązania kamienia cementowego z rurą/skałą i wpływa na wielkość mikroszczeliny. Dodatkowym problemem jest występowa-

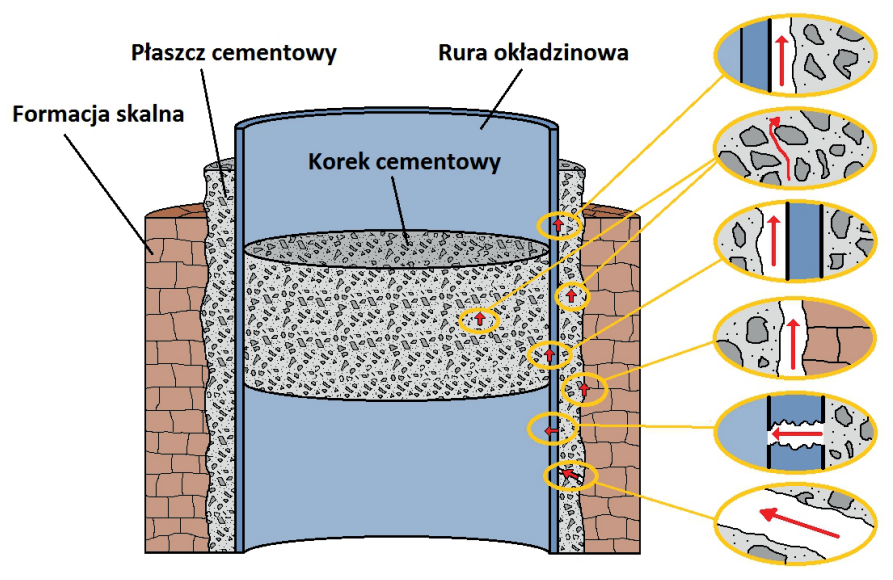

Rys. 1. Drogi migracji gazu w zacementowanym otworze wiertniczym

nie w tym regionie płytko zalegających horyzontów gazowych oraz poziomów ilasto-piaskowcowych nasyconych gazem. Są to często utwory słabozwięzłe, których przewiercanie wymaga stosowania odpowiednich inhibitowanych płuczek wiertniczych, a bezpośrednio przed zabiegiem cementowania osad płuczkowy powinien zostać jak najdokładniej usunięty $[1,3]$.

\section{Charakterystyka płuczek glikolowo-potasowych}

Rodzaj i parametry płuczek wiertniczych powinny być dostosowane do warunków geologiczno-złożowych oraz technologii wiercenia otworu. Odpowiednio dobrana płuczka ma za zadanie zapewniać prawidłowy i wolny od awarii proces wiercenia. Przewiercaniu warstw skał ilasto-łupkowych towarzyszy ryzyko wystąpienia komplikacji wiertniczych spowodowanych utratą stateczności ściany otworu. Wynika to ze szczególnej podatności tego rodzaju skał na zjawisko hydratacji, w wyniku której naruszona zostaje struktura krystaliczna minerałów. Dlatego też zasadnicze znaczenie ma rodzaj zastosowanej płuczki wiertniczej, a zwłaszcza jej właściwości ihibitacyjne. Płuczka taka powinna przede wszystkim wykazywać zdolność przeciwdziałania dyspersji i pęcznieniu materiałów ilastych, a także nie powodować pogorszenia przewodności hydraulicznej w strefie produkcyjnej [13].

Płuczki glikolowo-potasowe należą do grupy płuczek o podwójnym inhibitowaniu jonowo-polimerowym. Inhibi- towanie jonowe polega na zastosowaniu w składzie płuczki związków chemicznych będących źródłem anionów i kationów mogących wchodzić w reakcję wymiany jonowej z minerałami ilastymi [6]. Najbardziej korzystnym oddziaływaniem wyróżniają się związki potasu, a w szczególności chlorek potasu. Wynika to głównie z niewielkich rozmiarów jonów $\mathrm{K}^{+}$, dzięki którym podczas wymiany jonowej mogą one wnikać głęboko w przestrzenie międzywarstwowe minerałów ilastych. Łącząc pakiety iłów, powodują one powstanie wytrzymałej struktury o dużej odporności na uwadnianie i pęcznienie [2]. Inhibitowanie polimerowe w płuczkach glikolowo-potasowych realizowane jest przez działanie glikoli - bądź inaczej: poliglikoli. Są to polimery zaliczane do oligomerów, czyli polimerów o niskim stopniu polimeryzacji, posiadających cechy związków małocząsteczkowych. Dane literaturowe, a także otrzymane wyniki badań wskazują, że największą skutecznością inhibitowania hydratacji skał ilastych wyróżnia- 
ją się poliglikole o masie cząsteczkowej w granicach około $1000 \div 2000[10,11,12]$. Występują one w postaci stałej lub lepkich cieczy rozpuszczalnych w wodzie słodkiej o temperaturze pokojowej, wykazując ze wzrostem temperatury inwersję wzajemnej rozpuszczalności.

Inwersja wzajemnej rozpuszczalności w wodzie niektórych poliglikoli w funkcji temperatury polega na tym, że w miarę ogrzewania mieszaniny poliglikolu z wodą następuje stopniowe zmniejszanie jego rozpuszczalności i oddzielanie się go od wody. Temperatura, w której następuje rozdział faz w mieszaninie poprzez wydzielenie się poliglikolu w postaci mikrokropelek, nazywana jest temperaturą mętnienia lub punktem mętnienia. Zmętnienie jest skutkiem tworzenia się mikrokropelek poliglikolu w wodzie podczas ogrzewania. Zjawisko to jest odwracalne, gdyż w czasie ochładzania poliglikol ponownie ulega zmieszaniu $\mathrm{z}$ wodą.

Temperatura mętnienia nie jest wielkością stałą dla poszczególnych poliglikoli i ich mieszanin z wodą. Ulega ona obniżeniu wraz ze wzrostem masy cząsteczkowej oraz stężenia poliglikolu w wodzie, a także pod wpływem dodatków elektrolitów. Zjawisko to ma istotne znaczenie przy rozpatrywaniu mechanizmu inhibitującego działania poliglikoli na hydratację skał ilastych. Zagraniczne serwisy płuczkowe z dużym powodzeniem stosują również poliglikole, u których nie występuje zjawisko zmętnienia wraz ze wzrostem temperatury.

Mechanizm działania poliglikolu jako inhibitora hydratacji skał ilasto-łupkowych jest skomplikowany i dotychczas nie zostało wypracowane jednoznaczne wyjaśnienie tego zjawiska. Na podstawie wyników kompleksowych badań przeprowadzonych przez laboratoria chemiczne przyjęto, że poliglikol może penetrować do przestrzeni międzypakietowej minerałów ilastych i w zależności od właściwości chemicznych oraz ilości w cieczy - oddziaływać z ich powierzchniami za pomocą zewnętrznych grup hydroksylowych. Przenikając do skały, wypiera z niej wodę, ze względu na silniejsze powinowactwo iłu do glikolu aniżeli do wody, tworząc na powierzchniach minerałów ilastych warstwę poliglikolu, która zapobiega ich hydratacji. W powstawaniu tej warstwy biorą udział wiązania wodorowe.

Duże znaczenie ma również zjawisko rozdziału faz, polegające na wytrącaniu się mikrokropelek poliglikolu w płuczce wiertniczej w podwyższonej temperaturze, tj. powyżej punktu mętnienia. Oddzielająca się z płuczki faza poliglikolowa osadza się na ścianie otworu, tworząc warstwę hydrofobową nierozpuszczalną w płuczce wiertniczej. Jak wykazano, mechanizm inhibitowania hydratacji skał ilastych poliglikolem poniżej temperatury mętnienia może być mało skuteczny $[5,8,9]$.

\section{Metodyka określania przyczepności stwardniałego zaczynu cementowego do skał}

Podczas badań laboratoryjnych, których celem było określenie stopnia uszczelnienia przestrzeni pierścieniowej na kontakcie kamień cementowy-skała, stosowano próbki piaskowca pobranego z głębokości około 300-400 m. Użyte w trakcie badań laboratoryjnych próbki piaskowca zostały wycięte w kształcie walca o średnicy zewnętrznej $25 \mathrm{~mm}$ i długości $60 \mathrm{~mm}$ (fotografia 1).

W celu odwzorowania warunków otworowych oraz uzyskania jednakowych warunków wytwarzania osadów

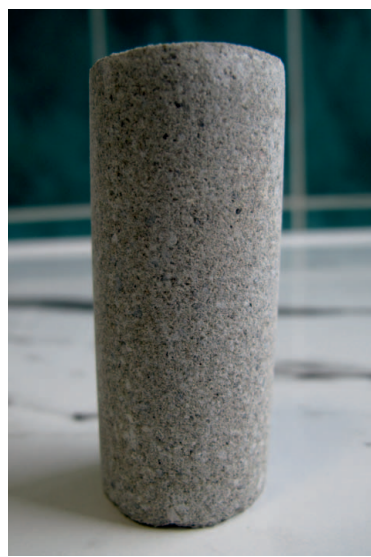

Fot. 1. Rdzeń wycięty $\mathrm{z}$ próbki piaskowca z płuczek wiertniczych na powierzchni - wycięte uprzednio rdzenie przetrzymywano przez 3 godziny w roztworze $\mathrm{NaCl}$

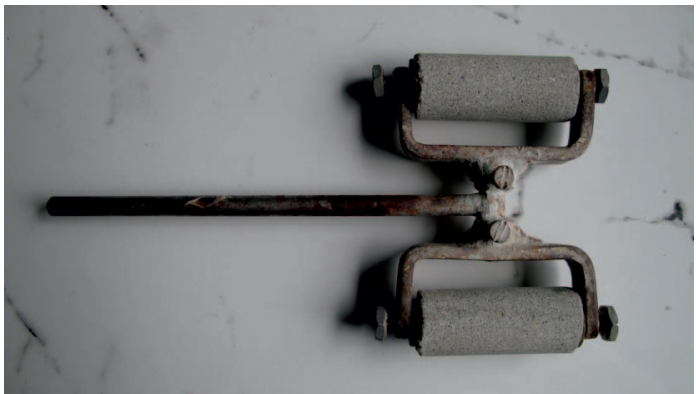

Fot. 2. Rdzenie piaskowca w uchwycie o stężeniu 5\%, a następnie poddawano suszeniu w temperaturze $105^{\circ} \mathrm{C}$. Utworzenie osadu płuczkowego wymagało zamocowania rdzeni w specjalnie zaprojektowanych uchwytach (fotografia 2), które zamontowane były w zaciskach mieszadeł płuczkowych. Kolejny krok stanowiło zanurzenie uchwytów wraz z rdzeniami w płuczce wiertniczej i obracanie przez 1 godzinę z prędkością obrotową około $150 \mathrm{obr} . \mathrm{min}$, co miało na celu symulowanie warunków panujących w otworze. Taka prędkość obrotowa wynika z obliczeń uwzględniających odległość rdzeni od osi obrotu oraz najczęściej spotykane wydatki tłoczenia płuczki podczas płukania otworu. Czas mieszania i tworzenia osadu określony został na podstawie wstępnych prób i obserwacji prowadzonych podczas testów przygotowujących próbki rdzenia do badań.

Po wytworzeniu osadu na rdzeniach przenoszone były one do cieplarki, a następnie przetrzymywane $\mathrm{w}$ temperaturze $40^{\circ} \mathrm{C}$ przez 30 minut. Miało to na celu ustabilizowanie osadu na powierzchni rdzenia. Później rdzenie $\mathrm{z}$ naniesionym osadem ponownie umieszczano w uchwytach, zanurzano w cieczy przemywającej i wykonywano próbę usunięcia osadu 
przez mieszanie z prędkością obrotową około $150 \mathrm{obr} / \mathrm{min}$ w czasie 15 minut. Kolejnym krokiem było obracanie rdzeni w środowisku cieczy buforowej; podobnie jak w przypadku cieczy przemywającej mieszanie odbywało się przy prędkości obrotowej $150 \mathrm{obr}$./min przez okres 15 minut.

Po wypłukaniu osadu płuczkowego za pomocą cieczy przemywającej i cieczy buforowej przystępowano do kolejnego etapu badań, których celem było określenie efektywności uszczelnienia przestrzeni pierścieniowej na kontakcie kamień cementowy-skała. Badania te przeprowadzono, opierając się na pomiarze przyczepności kamienia cementowego do próbki skały.

W trakcie badań przyczepności kamienia cementowego do próbki skały użyte zostały pierścienie z tworzywa sztucznego, wewnątrz których centralnie ustawiano rdzenie z przemytym osadem. Formy z umieszczonym współśrodkowo rdzeniem zalewano zaczynem cementowym, którego recepturę i właściwości przedstawiono w tablicy 2 i na rysunku 2. Następnie przechowywano je w temperaturze $20^{\circ} \mathrm{C}$ i $80^{\circ} \mathrm{C}$ w otoczeniu wody przez okres dwóch oraz siedmiu dni. Po sezonowaniu, czyli wystawieniu próbek na oddziaływanie temperatury, umieszczano je między dwiema płytami maszyny wytrzymałościowej, gdzie mierzono siłę zerwania przyczepności na kontakcie kamień cementowy-skała pod wpływem obciążenia przykładanego na próbkę.

Po każdym pomiarze siły potrzebnej do zerwania przyczepności pomiędzy kamieniem cementowym a skałą należało obliczyć przyczepność wyrażoną w MPa, według wzoru (1):

$$
\sigma_{p}=\frac{P}{S} \cdot 10^{-3}[\mathrm{MPa}]
$$

gdzie:

$P$ - siła nacisku powodująca zerwanie połączenia kamienia cementowego ze skałą [kN],

$s$ - powierzchnia styku próbki skały z kamieniem cementowym $[\mathrm{m}]$.

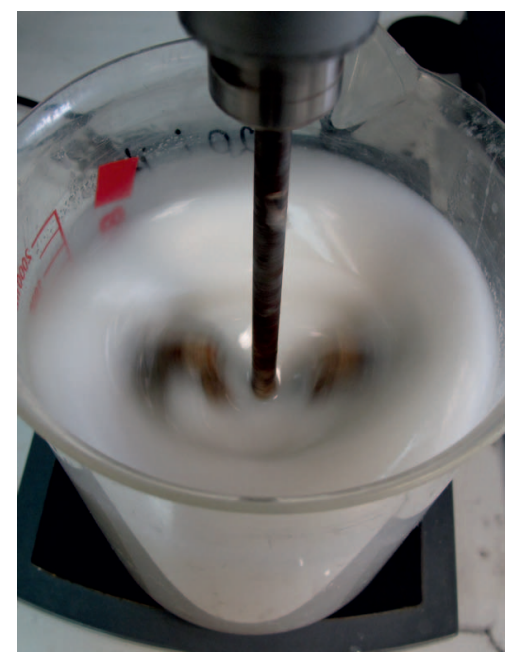

Fot. 3. Wytwarzanie osadu płuczkowego na rdzeniach

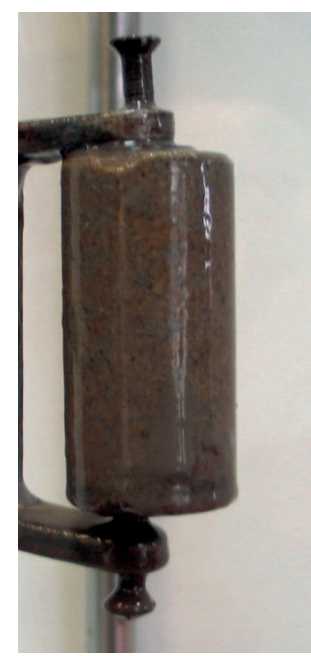

Fot. 7. Rdzeń po przemyciu cieczą przemywającą

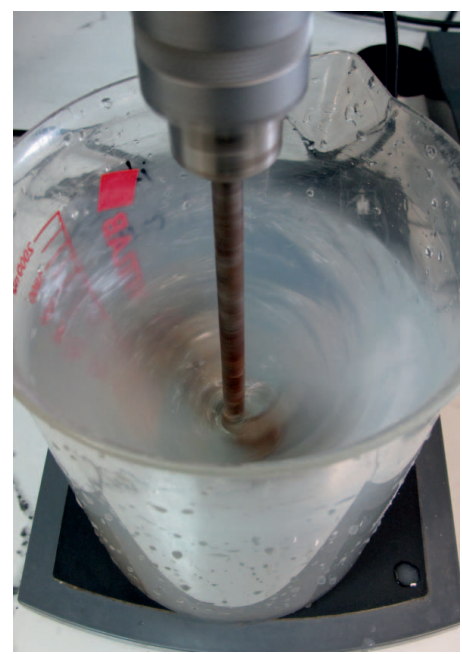

Fot. 4. Usuwanie osadu płuczkowego przez mieszanie w cieczy przemywającej

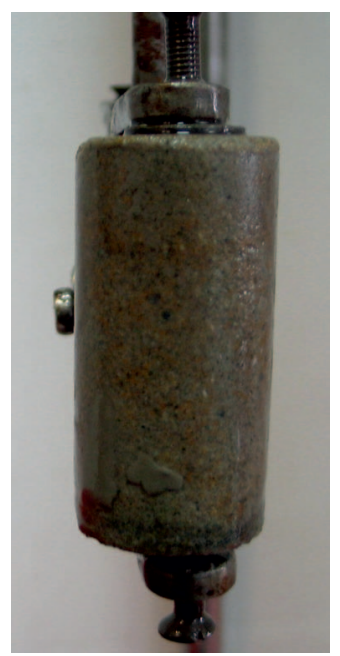

Fot. 6. Osad płuczkowy wytworzony na rdzeniu

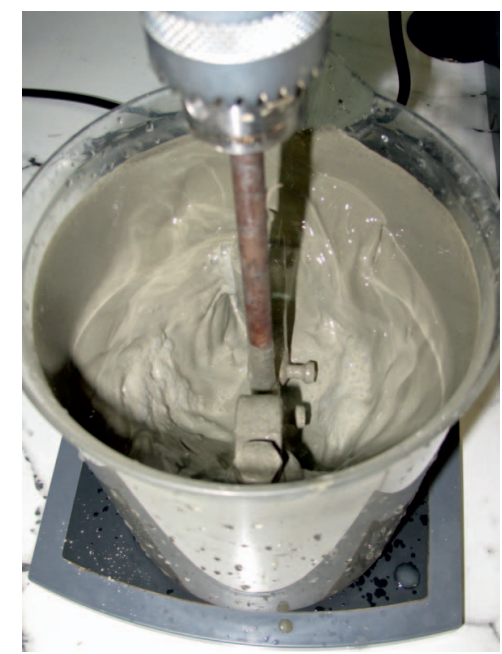

Fot. 5. Usuwanie osadu płuczkowego przez mieszanie w cieczy buforowej

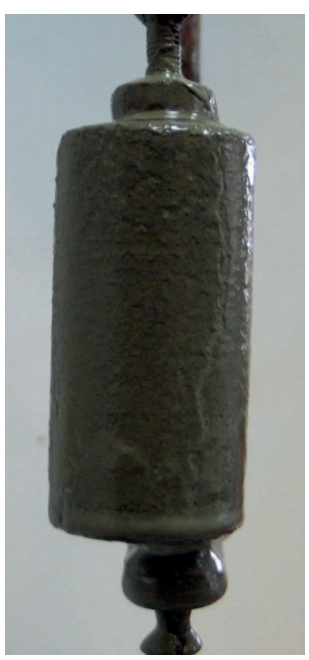

Fot. 8. Rdzeń po przemyciu cieczą buforową 


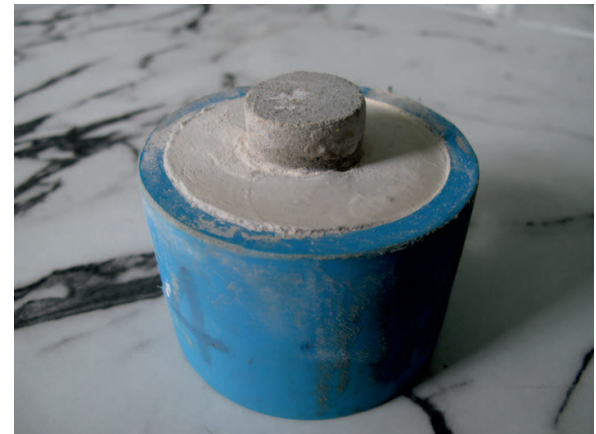

Fot. 9. Rdzeń wycięty z piaskowca zacementowany w formie

Siłę nacisku $(P)$ odczytywano bezpośrednio ze wskaźnika maszyny wytrzymałościowej, natomiast powierzchnia styku skały z kamieniem cementowym wynikała z geometrii form, w których rdzenie były zalewane zaczynem cementowym.

Z rysunku 2 można odczytać wymiary potrzebne do obliczenia powierzchni styku skały z kamieniem cementowym. Są to:

- średnica rdzenia $(d): 25 \mathrm{~mm}=0,025 \mathrm{~m}$;

- wysokość zacementowanej części rdzenia $(h)$ : $44 \mathrm{~mm}=0,044 \mathrm{~m}$.

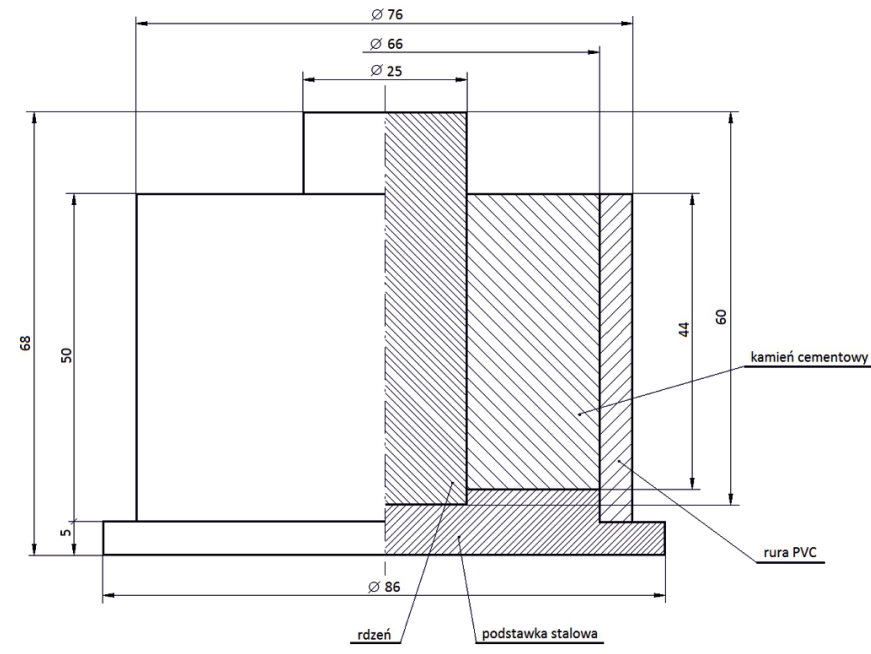

Rys. 2. Półprzekrój formy

$$
s=\pi \cdot d \cdot h
$$

$$
s=\pi \cdot 0,025 \cdot 0,044=0,003456\left[\mathrm{~m}^{2}\right]
$$

stąd:

$$
\sigma_{p}=\frac{P}{0,003456} \cdot 10^{-3}=\frac{P}{3,456}[\mathrm{MPa}]
$$

\section{Wyniki badań laboratoryjnych}

Do badań laboratoryjnych przeprowadzonych w ramach realizacji niniejszej pracy wybrano płuczki o podwójnym inhibitowaniu polimerowo-jonowym. Pierwszym rodzajem była płuczka glikolowo-potasowa, w której wykorzystano
R26+R30P5 - dwuskładnikowy poliglikol stosowany w składach płuczek opracowanych w INiG - PIB. Jest to blokowy kopolimer tlenku etylenu i tlenku propylenu w połączeniu

\begin{tabular}{|c|c|c|c|c|c|c|c|c|c|c|c|c|c|c|}
\hline \multirow{3}{*}{\multicolumn{2}{|c|}{$\begin{array}{l}\text { Skład płuczki } \\
\text { wiertniczej }\end{array}$}} & \multirow{2}{*}{\multicolumn{2}{|c|}{ Fann 35}} & \multirow{3}{*}{$\begin{array}{l}\text { Gęstość } \\
{\left[\mathrm{g} / \mathrm{cm}^{3}\right]}\end{array}$} & \multirow{2}{*}{\multicolumn{2}{|c|}{$\begin{array}{l}\text { Lepkość } \\
{[\mathrm{mPa} \cdot \mathrm{s}]}\end{array}$}} & \multirow{3}{*}{$\begin{array}{c}\text { Granica } \\
\text { płynięcia } \\
{[\mathrm{Pa}]} \\
\tau_{y}\end{array}$} & \multirow{3}{*}{$\begin{array}{c}\text { Wytrzymałość } \\
\text { strukturalna } \\
{[\mathrm{Pa}]}\end{array}$} & \multirow{3}{*}{$\begin{array}{c}\text { Filtracja } \\
\text { API } \\
{\left[\mathrm{cm}^{3}\right]}\end{array}$} & \multirow{3}{*}{$\mathrm{pH}$} & \multicolumn{4}{|c|}{$\begin{array}{c}\text { Dyspersja } \\
{[\%]}\end{array}$} \\
\hline & & & & & & & & & & & \multicolumn{2}{|c|}{$20^{\circ} \mathrm{C}$} & \multicolumn{2}{|c|}{$80^{\circ} \mathrm{C}$} \\
\hline & & $\begin{array}{c}{[\mathrm{obr} . /} \\
\mathrm{min}]\end{array}$ & odczyt & & $\eta_{p l}$ & $\eta_{s}$ & & & & & $P_{1}$ & $P_{2}$ & $P_{1}$ & $P_{2}$ \\
\hline $\begin{array}{l}\text { Biostat } \\
\text { PAC LV } \\
\text { PAC R } \\
\text { XCD } \\
\text { Rotomag } \\
\mathrm{KCl} \\
\text { R26 } \\
\text { R30P5 } \\
\text { M25 }\end{array}$ & $\begin{array}{l}0,10 \% \\
0,30 \% \\
0,15 \% \\
0,15 \% \\
3,00 \% \\
5,00 \% \\
1,00 \% \\
3,00 \% \\
5,00 \% \\
\end{array}$ & $\begin{array}{r}600 \\
300 \\
200 \\
100 \\
6 \\
3\end{array}$ & $\begin{array}{r}79 \\
56 \\
44 \\
31 \\
8 \\
6\end{array}$ & 1,06 & 23 & 39,5 & 15,8 & 2,9 & 4,2 & 9,3 & 98 & 68 & 96 & 54 \\
\hline $\begin{array}{l}\text { Biostat } \\
\text { PAC LV } \\
\text { PAC R } \\
\text { XCD } \\
\text { Rotomag } \\
\text { Stabpol } \\
\text { KCl } \\
\text { M25 }\end{array}$ & $\begin{array}{l}0,10 \% \\
0,30 \% \\
0,15 \% \\
0,15 \% \\
3,00 \% \\
0,30 \% \\
5,00 \% \\
5,00 \%\end{array}$ & $\begin{array}{r}600 \\
300 \\
200 \\
100 \\
6 \\
3\end{array}$ & $\begin{array}{r}128 \\
90 \\
73 \\
50 \\
11 \\
8\end{array}$ & 1,06 & 38 & 64,0 & 24,9 & 3,8 & 4,4 & 9,4 & 96 & 38 & 86 & 24 \\
\hline
\end{tabular}
z oksyetylenowanym trójglicerydem kwasu rycynolowego.

Tablica 1. Skład oraz parametry płuczek zastosowanych w badaniach 
Drugim rodzajem płuczki była płuczka polimerowo-potasowa, którą uwzględniono w badaniach w celu porównania oddziaływania na jakość zacementowania z płuczkami glikolowo-potasowymi. W składzie tej płuczki oprócz chlorku potasu, który pełnił rolę jonowego inhibitora hydratacji skał ilastych, znajdował się polimer kapsułujący, czyli częściowo hydrolizowany poliakryloamid (znany również jako PHPA).

Obydwa rodzaje płuczek wykorzystanych w badaniach laboratoryjnych opierały się na tym samym zestawie polimerów strukturotwórczych. Były to: PAC LV, PAC R, XCD oraz Rotomag. Podobnie w obydwu rodzajach płuczek jednym z zastosowanych inhibitorów hydratacji łupków był chlorek potasu.

W celu opracowania skutecznej cieczy przemywającej przebadano szereg substancji, takich jak:

- MudClean - środek szeroko stosowany w technologii wiertniczej do sporządzania cieczy przemywających, mających za zadanie przygotowanie otworu do zabiegu cementowania,

- RNL8 - mieszanina etoksylowanych alkoholi tłuszczowych; jako środek powierzchniowo czynny znajduje szerokie zastosowanie w przemyśle kosmetycznym oraz jako składnik produktów czyszczących,

- C - alkilopoliglukozyd alkoholu tłuszczowego, używany jako niejonowy związek powierzchniowo czynny do produkcji przemysłowych środków myjących,

- alkohol etylowy.

Badanie efektywności działania cieczy przemywających, zawierających wymienione wyżej substancje, polegało na piętnastominutowym przemywaniu osadu płuczkowego wytworzonego na rdzeniu, a następnie zacementowaniu i sprawdzeniu przyczepności na maszynie wytrzymałościowej.

\section{Badanie przyczepności na kontakcie kamień cementowy-skała}

Najważniejszym badaniem, pozwalającym określić wpływ płuczek wiertniczych na jakość zacementowania, było badanie przyczepności na kontakcie stwardniały zaczyn cementowy-skała. Pierwszy krok stanowiło wyznaczenie przyczepności bazowej (lub inaczej przyczepności początkowej, odniesienia), do której odnoszono wyniki kolejnych badań. $\mathrm{W}$ celu jej określenia rdzenie wycięte $\mathrm{z}$ piaskowca zostały zalane zaczynem cementowym, z pominięciem etapu przemywania w cieczy przemywającej i buforze.

W tablicy 2 oraz na rysunku 3 przedstawione zostały wartości przyczepności bazowej (odniesienia) uzyskanej w temperaturach $20^{\circ} \mathrm{C}$ oraz $80^{\circ} \mathrm{C}$, po dwu- i siedmiodniowym sezonowaniu. Widać wyraźnie, że przyczepność kamienia cementowego jest niemal dwukrotnie wyższa po sezonowaniu w niższej temperaturze.

Niepewność uzyskanych wyników pomiarów zaprezentowanych w tablicach 1-3 oznaczono na podstawie klasy dokładności urządzeń pomiarowych na poziomie: $0,2 \%$ dla pomiarów reologicznych oraz $0,6 \%$ dla pomiarów przyczepności na kontakcie kamień cementowy-skała.
Tablica 2. Bazowa przyczepność na kontakcie kamień cementowy-skała

\begin{tabular}{|l|c|c|c|c|}
\hline \multicolumn{1}{|c|}{ Temperatura $\left[{ }^{\circ} \mathrm{C}\right.$ ] } & \multicolumn{2}{|c|}{20} & \multicolumn{2}{c|}{80} \\
\hline Czas sezonowania [dni] & 2 & 7 & 2 & 7 \\
\hline Siła zerwania przyczepności [kN] & 7,9 & 8,2 & 4,2 & 4,8 \\
\hline $\begin{array}{l}\text { Przyczepność na kontakcie kamień } \\
\text { cementowy-skała [MPa] }\end{array}$ & $\mathbf{2 , 2 8}$ & $\mathbf{2 , 3 7}$ & $\mathbf{1 , 2 1}$ & $\mathbf{1 , 3 9}$ \\
\hline
\end{tabular}

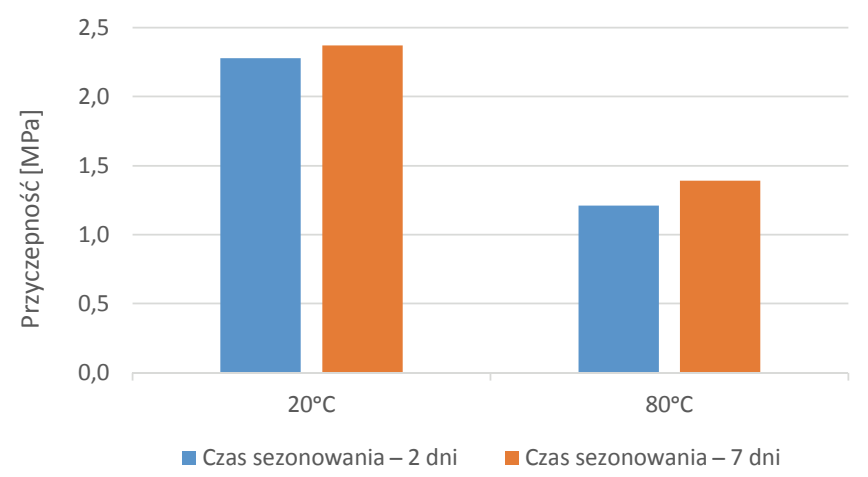

Rys. 3. Bazowa przyczepność na kontakcie kamień cementowy-skała

\section{Analiza skuteczności działania badanych cieczy przemywających}

W toku badań laboratoryjnych sprawdzono skuteczność zmywania osadów płuczkowych przez sześć cieczy przemywających:

- wodę,

- wodny roztwór środka MudClean (1\%),

- wodny roztwór środka RNL8 (5\%),

- wodny roztwór etanolu (30\%) i RNL8 (5\%),

- wodny roztwór C (5\%),
- wodny roztwór C (5\%) i RNL8 (5\%).

Uzyskane wyniki przedstawiono na wykresach 4-7.

W temperaturze $20^{\circ} \mathrm{C}$ po dwudniowym sezonowaniu próbek najniższą skutecznością działania odznaczyła się ciecz przemywająca oparta na alkoholu etylowym i RNL8. Wartości przyczepności uzyskanej po oddziaływaniu obydwu płuczek wynosiły około $0,5 \mathrm{MPa}$, co stanowiło około $20 \div 25 \%$ przyczepności bazowej. Co znamienne, uzyskane dla tej cieczy 
Tablica 3. Przyczepność na kontakcie kamień cementowy-skała po zastosowaniu badanych cieczy przemywających

\begin{tabular}{|c|c|c|c|c|c|}
\hline \multirow{2}{*}{ Rodzaj płuczki } & \multirow{2}{*}{$\frac{\text { Temperatura }\left[{ }^{\circ} \mathrm{C}\right]}{\text { Czas sezonowania próbki }[\mathrm{dni}]}$} & \multicolumn{2}{|c|}{20} & \multicolumn{2}{|c|}{80} \\
\hline & & 2 & 7 & 2 & 7 \\
\hline \multicolumn{6}{|c|}{ Brak cieczy przemywającej } \\
\hline \multirow{3}{*}{$\begin{array}{l}\text { Płuczka glikolowo- } \\
\text { potasowa }\end{array}$} & Siła zerwania przyczepności $[\mathrm{kN}]$ & 2,1 & 1,6 & 1,5 & 1,6 \\
\hline & Przyczepność na kontakcie kamień cementowy-skała [MPa] & 0,61 & 0,46 & 0,43 & 0,46 \\
\hline & Procentowa zmiana przyczepności w stosunku do przyczepności bazowej & $\downarrow \mathbf{7 3 \%}$ & $\downarrow 81 \%$ & $\downarrow 64 \%$ & $\downarrow 67 \%$ \\
\hline \multirow{3}{*}{$\begin{array}{l}\text { Płuczka polimero- } \\
\text { wo-potasowa }\end{array}$} & Siła zerwania przyczepności $[\mathrm{kN}]$ & 2,2 & 2,4 & 2,3 & 2,5 \\
\hline & Przyczepność na kontakcie kamień cementowy-skała [MPa] & 0,64 & 0,69 & 0,66 & 0,72 \\
\hline & Procentowa zmiana przyczepności w stosunku do przyczepności bazowej & $\downarrow 72 \%$ & $\downarrow 71 \%$ & $\downarrow 45 \%$ & $\downarrow 48 \%$ \\
\hline \multicolumn{6}{|c|}{ Woda } \\
\hline \multirow{3}{*}{$\begin{array}{l}\text { Płuczka glikolowo- } \\
\text { potasowa }\end{array}$} & Siła zerwania przyczepności $[\mathrm{kN}]$ & 3,3 & 3,7 & 2,6 & 2,9 \\
\hline & Przyczepność na kontakcie kamień cementowy-skała [MPa] & 0,95 & 1,07 & 0,75 & 0,84 \\
\hline & Procentowa zmiana przyczepności w stosunku do przyczepności bazowej & $\downarrow \mathbf{5 8 \%}$ & $\downarrow 55 \%$ & $\downarrow \mathbf{3 8 \%}$ & $\downarrow 40 \%$ \\
\hline \multirow{3}{*}{$\begin{array}{l}\text { Płuczka polimero- } \\
\text { wo-potasowa }\end{array}$} & Siła zerwania przyczepności $[\mathrm{kN}]$ & 3,4 & 3,7 & 3,8 & 4,0 \\
\hline & Przyczepność na kontakcie kamień cementowy-skała [MPa] & 0,98 & 1,07 & 1,10 & 1,16 \\
\hline & Procentowa zmiana przyczepności w stosunku do przyczepności bazowej & $\downarrow 44 \%$ & $\downarrow \mathbf{5 5 \%}$ & $\downarrow 9 \%$ & $\downarrow 16 \%$ \\
\hline \multicolumn{6}{|c|}{ Wodny roztwór MudClean (1\%) } \\
\hline \multirow{3}{*}{$\begin{array}{l}\text { Płuczka glikolowo- } \\
\text { potasowa }\end{array}$} & Siła zerwania przyczepności $[\mathrm{kN}]$ & 4,7 & 5,9 & 2,9 & 4,3 \\
\hline & Przyczepność na kontakcie kamień cementowy-skała [MPa] & 1,36 & 1,70 & 0,84 & 1,24 \\
\hline & Procentowa zmiana przyczepności w stosunku do przyczepności bazowej & $\downarrow 40 \%$ & $\downarrow \mathbf{2 8 \%}$ & $\downarrow \mathbf{3 0 \%}$ & $\downarrow 11 \%$ \\
\hline \multirow{3}{*}{$\begin{array}{l}\text { Płuczka polimero- } \\
\text { wo-potasowa }\end{array}$} & Siła zerwania przyczepności $[\mathrm{kN}]$ & 4,5 & 5,5 & 3,6 & 4,2 \\
\hline & Przyczepność na kontakcie kamień cementowy-skała [MPa] & 1,30 & 1,59 & 1,04 & 1,21 \\
\hline & Procentowa zmiana przyczepności w stosunku do przyczepności bazowej & $\downarrow 43 \%$ & $\downarrow 33 \%$ & $\downarrow 14 \%$ & $\downarrow 13 \%$ \\
\hline \multicolumn{6}{|c|}{ Wodny roztwór RNL8 (5\%) } \\
\hline \multirow{3}{*}{$\begin{array}{l}\text { Płuczka glikolowo- } \\
\text { potasowa }\end{array}$} & Siła zerwania przyczepności $[\mathrm{kN}]$ & 3,7 & 3,8 & 3,4 & 3,8 \\
\hline & Przyczepność na kontakcie kamień cementowy-skała [MPa] & 1,07 & 1,10 & 0,98 & 1,10 \\
\hline & Procentowa zmiana przyczepności w stosunku do przyczepności bazowej & $\downarrow \mathbf{5 3 \%}$ & $\downarrow \mathbf{5 4 \%}$ & $\downarrow 19 \%$ & $\downarrow 21 \%$ \\
\hline \multirow{3}{*}{$\begin{array}{l}\text { Płuczka polimero- } \\
\text { wo-potasowa }\end{array}$} & Siła zerwania przyczepności $[\mathrm{kN}]$ & 5,4 & 5,9 & 3,8 & 4,4 \\
\hline & Przyczepność na kontakcie kamień cementowy-skała [MPa] & 1,56 & 1,70 & 1,10 & 1,27 \\
\hline & Procentowa zmiana przyczepności w stosunku do przyczepności bazowej & $\downarrow 32 \%$ & $\downarrow \mathbf{2 8 \%}$ & $\downarrow 9 \%$ & $\downarrow 9 \%$ \\
\hline \multicolumn{6}{|c|}{ Wodny roztwór etanolu (30\%) i RNL8 (5\%) } \\
\hline \multirow{3}{*}{$\begin{array}{l}\text { Płuczka glikolowo- } \\
\text { potasowa }\end{array}$} & Siła zerwania przyczepności $[\mathrm{kN}]$ & 1,8 & 2,5 & 1,8 & 2,4 \\
\hline & Przyczepność na kontakcie kamień cementowy-skała [MPa] & 0,52 & 0,72 & 0,52 & 0,69 \\
\hline & Procentowa zmiana przyczepności w stosunku do przyczepności bazowej & $\downarrow \mathbf{7 7 \%}$ & $\downarrow \mathbf{7 0 \%}$ & $\downarrow 57 \%$ & $\downarrow \mathbf{5 0 \%}$ \\
\hline \multirow{3}{*}{$\begin{array}{l}\text { Płuczka polimero- } \\
\text { wo-potasowa }\end{array}$} & Siła zerwania przyczepności [kN] & 2,0 & 2,4 & 2,2 & 2,5 \\
\hline & Przyczepność na kontakcie kamień cementowy-skała [MPa] & 0,58 & 0,69 & 0,64 & 0,72 \\
\hline & Procentowa zmiana przyczepności w stosunku do przyczepności bazowej & $\downarrow \mathbf{7 5 \%}$ & $\downarrow 71 \%$ & $\downarrow 47 \%$ & $\downarrow 48 \%$ \\
\hline \multicolumn{6}{|c|}{ Wodny roztwór C $(5 \%)$} \\
\hline \multirow{3}{*}{$\begin{array}{l}\text { Płuczka glikolowo- } \\
\text { potasowa }\end{array}$} & Siła zerwania przyczepności $[\mathrm{kN}]$ & 3,9 & 5,0 & 2,4 & 3,4 \\
\hline & Przyczepność na kontakcie kamień cementowy-skała [MPa] & 1,13 & 1,44 & 0,69 & 0,98 \\
\hline & Procentowa zmiana przyczepności w stosunku do przyczepności bazowej & $\downarrow \mathbf{5 0 \%}$ & $\downarrow 39 \%$ & $\downarrow 43 \%$ & $\downarrow 29 \%$ \\
\hline & Siła zerwania przyczepności $[\mathrm{kN}]$ & 3,6 & 4,4 & 3,5 & 4,1 \\
\hline fuczka poim & Przyczepność na kontakcie kamień cementowy-skała [MPa] & 1,04 & 1,27 & 1,01 & 1,18 \\
\hline & Procentowa zmiana przyczepności w stosunku do przyczepności bazowej & $\downarrow \mathbf{5 4 \%}$ & $\downarrow 46 \%$ & $\downarrow 16 \%$ & $\downarrow 15 \%$ \\
\hline & Wodny roztwór C (5\%) i RNL8 (5\%) & & & & \\
\hline & Siła zerwania przyczepności [kN] & 4,9 & 5,6 & 4,0 & 4,5 \\
\hline potasowa & Przyczepność na kontakcie kamień cementowy-skała [MPa] & 1,42 & 1,62 & 1,16 & 1,3 \\
\hline & Procentowa zmiana przyczepności w stosunku do przyczepności bazowej & $\downarrow \mathbf{3 8 \%}$ & $\downarrow \mathbf{3 2 \%}$ & $\downarrow 4 \%$ & $\downarrow 6 \%$ \\
\hline & Siła zerwania przyczepności $[\mathrm{kN}]$ & 4,6 & 5,6 & 4,1 & 4,5 \\
\hline PruczKa polime & Przyczepność na kontakcie kamień cementowy-skała [MPa] & 1,33 & 1,62 & 1,18 & 1,30 \\
\hline & Procentowa zmiana przyczepności w stosunku do przyczepności bazowej & $\downarrow 42 \%$ & $\downarrow 32 \%$ & $\downarrow 2 \%$ & $\downarrow 6 \%$ \\
\hline
\end{tabular}


wyniki były gorsze nawet od przyczepności otrzymanych bez żadnej cieczy przemywającej. Dużo wyższą skuteczność działania zapewniały ciecze przemywające zawierające MudClean i RNL8. Były to wartości w przedziale $1,0 \div 1,4 \mathrm{MPa}$, a nawet $1,56 \mathrm{MPa}$ $\mathrm{w}$ przypadku płuczki polimerowo-potasowej.

Jednak najlepszą efektywnością charakteryzowała się ciecz oparta na środku C i RNL8. W tym przypadku uzyskane wyniki zawierały się w przedziale $1,3 \div 1,4 \mathrm{MPa}$, co stanowiło około $60 \%$ bazowej przyczepności kamienia cementowego do skały.

Po siedmiodniowym sezonowaniu próbek w temperaturze $20^{\circ} \mathrm{C}$ wyniki były bardzo podobne do tych uzyskanych po dwóch dniach. Ponownie ciecz zawierająca w swoim składzie alkohol etylowy i RNL8 prezentowała najniższą skuteczność działania. Ciecz zawierająca C i RNL8 kolejny raz zapewniła bardzo dobrą skuteczność w usuwaniu osadów, a ponadto działała jednakowo na każdy z nich. Otrzymane wartości przyczepności mieściły się $\mathrm{w}$ wąskim zakresie 1,5 $\div 1,6 \mathrm{MPa}$, co stanowiło około $65 \div 70 \%$ wartości bazowej.

Wyniki pomiaru przyczepności w temperaturze $80^{\circ} \mathrm{C}$ były generalnie niższe niż uzyskiwane w temperaturze $20^{\circ} \mathrm{C}$, jednak również przyczepność bazowa stwardniałego zaczynu cementowego do skały była niemal dwukrotnie niższa niż w temperaturze $20^{\circ} \mathrm{C}$.

Najniższym stopniem wymywania osadów płuczkowych w temperaturze $80^{\circ} \mathrm{C}$ po dwudniowym sezonowaniu próbek charakteryzowała się ciecz oparta na etanolu i RNL8. Podobnie jak w temperaturze $20^{\circ} \mathrm{C}$ efektywność tej cieczy jest znikoma, a wyniki porówny-

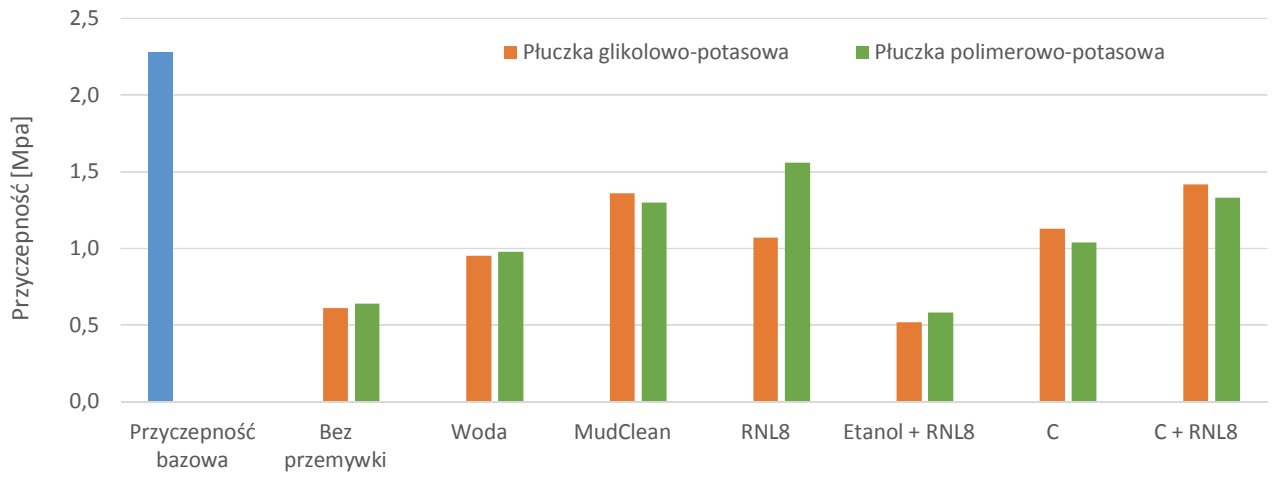

Rys. 4. Wyniki badania przyczepności kamienia cementowego do skały uzyskane w temperaturze $20^{\circ} \mathrm{C}$ po dwóch dniach

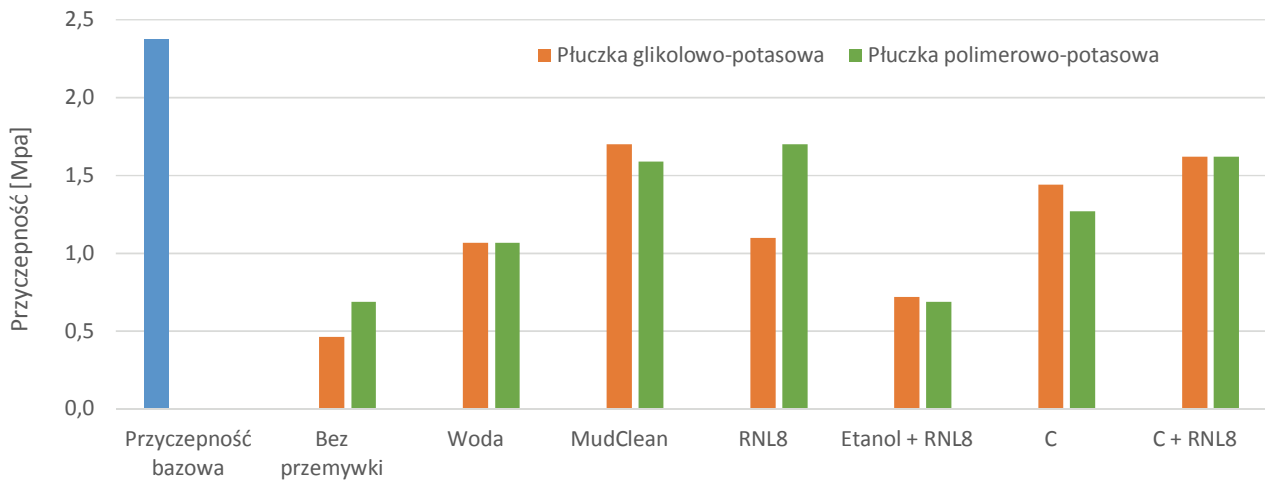

Rys. 5. Wyniki badania przyczepności kamienia cementowego do skały uzyskane $\mathrm{w}$ temperaturze $20^{\circ} \mathrm{C}$ po siedmiu dniach

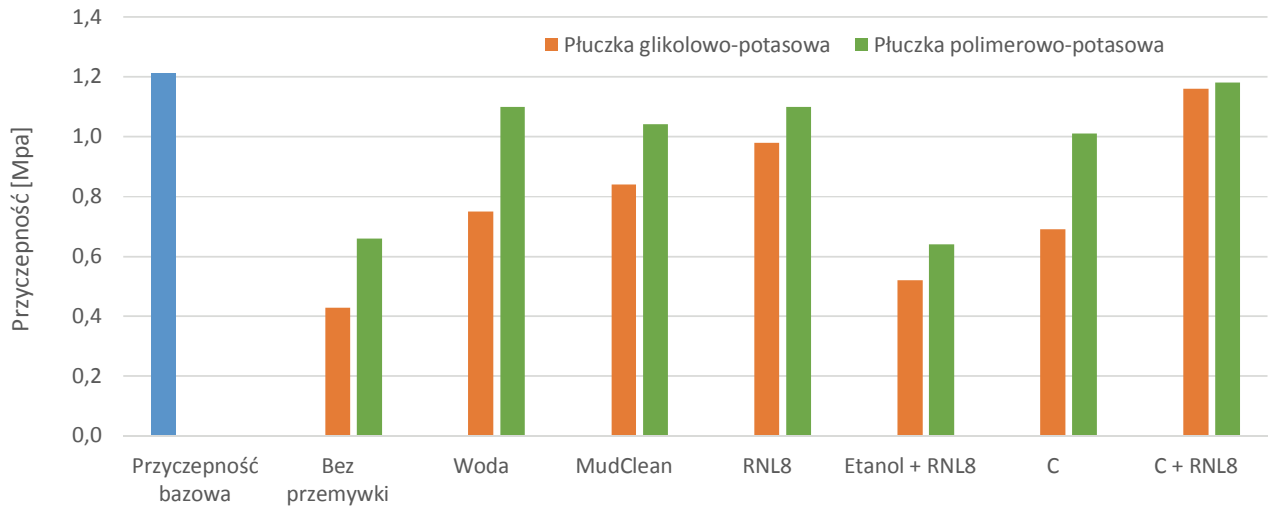

Rys. 6. Wyniki badania przyczepności kamienia cementowego do skały uzyskane w temperaturze $80^{\circ} \mathrm{C}$ po dwóch dniach

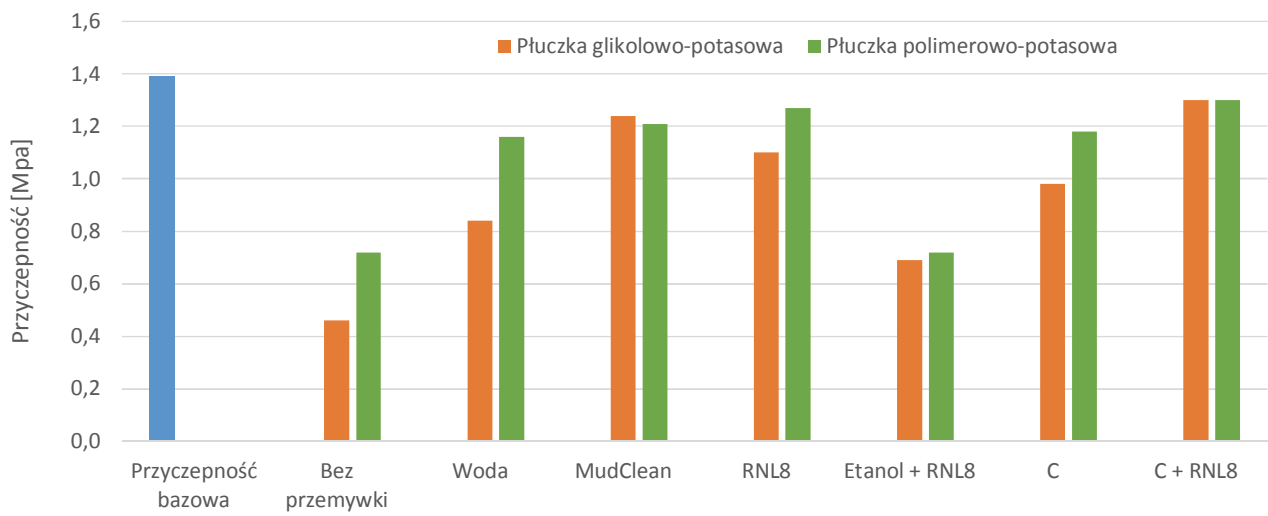

Rys. 7. Wyniki badania przyczepności kamienia cementowego do skały uzyskane w temperaturze $80^{\circ} \mathrm{C}$ po siedmiu dniach 
walne z uzyskanymi po cementowaniu bez żadnej cieczy przemywającej. Co ciekawe, stosunkowo wysoką skuteczność zacementowania osiągnięto po przemyciu rdzeni wodą. Ponownie najlepiej działającą cieczą był wodny roztwór C i RNL8.

W temperaturze $80^{\circ} \mathrm{C}$ po siedmiu dniach sezonowania próbek najniższą skutecznością działania odznaczyła się ciecz przemywająca oparta na alkoholu etylowym i RNL8.
Wartości przyczepności uzyskanej po oddziaływaniu obydwu płuczek oscylowały w przedziale $0,69 \div 0,72 \mathrm{MPa}$, co stanowiło około 40 $\div 50 \%$ przyczepności bazowej. Najwyższą efektywnością cechowała się ponownie ciecz oparta na C i RNL8. Obydwa uzyskane w tym przypadku wyniki wynosiły 1,3 MPa, co stanowiło około 95\% bazowej przyczepności kamienia cementowego do skały.

\section{Podsumowanie i wnioski końcowe}

Celem badań było opracowanie metody usuwania osadu płuczkowego ze ściany otworu, aby zapewnić jak najlepsze połączenie na kontakcie stwardniały zaczyn cementowy-skała. Jako składniki badanych cieczy przemywających wykorzystano: MudClean - środek szeroko stosowany w technologii wiertniczej do sporządzania cieczy przemywających mających za zadanie przygotowanie otworu do zabiegu cementowania, etoksylowane alkohole thuszczowe, alkilopoliglukozyd alkoholu tłuszczowego oraz alkohol etylowy. Badanie efektywności ich działania polegało na piętnastominutowym przemywaniu osadu płuczkowego wytworzonego na rdzeniu, a następnie zacementowaniu i sprawdzeniu przyczepności na maszynie wytrzymałościowej. Analiza wyników badań laboratoryjnych realizowanych w ramach niniejszej pracy pozwala przedstawić następujące wnioski:
1. Przyczepność bazowa wyznaczona na początku badań jakości zacementowania jest niemal dwukrotnie wyższa po cementowaniu w temperaturze $20^{\circ} \mathrm{C}$ niż w $80^{\circ} \mathrm{C}$.

2. Spośród przebadanych cieczy przemywających najmniejszą skutecznością charakteryzuje się wodny roztwór etanolu i RNL8.

3. Najwyższą efektywnością usuwania osadów płuczkowych, a co za tym idzie - poprawą skuteczności cementowania odznacza się ciecz przemywająca, w której znajduje się 5\% C oraz 5\% RNL8. Bardzo dobra skuteczność w oczyszczaniu skały z osadu płuczkowego występuje zarówno w niskiej, jak i wysokiej temperaturze, co jest szczególnie ważne z uwagi na stosowanie płuczki glikolowo-potasowej do przewiercania głębokich interwałów, w których panuje podwyższona temperatura.

Prosimy cytować jako: Nafta-Gaz 2016, nr 6, s. 413-421, DOI: 10.18668/NG.2016.06.04

Artykuł nadesłano do Redakcji 20.11.2015 r. Zatwierdzono do druku 10.03.2016 r.

Artykuł powstał na podstawie pracy statutowej pt. Analiza wpływu poliglikoli stosowanych w płuczkach wiertniczych na jakość zacementowania rur okładzinowych - praca INiG - PIB na zlecenie MNiSW; nr zlecenia: 0039/KW/15, nr archiwalny: DK-4100-39/15.

\section{Literatura}

[1] Gawlik P., Szymczak M.: Migracje gazowe w przestrzeniach międzyrurowych otworów realizowanych na przedgórzu Karpat w roku 2005. Prace Instytutu Nafty i Gazu nr 137, Kraków 2006.

[2] Guerrero M., Guerrero X.: Use of Amine/PHPA System To Drill High Reactive Shales in the Orito Field in Colombia. SPE104010-MS, 2006.

[3] Kremieniewski M., Rzepka M., Dębińska E.: Statyczna wytrzymałość strukturalna zaczynów przeznaczonych do uszczelniania otworów o podwyższonym ryzyku występowania migracji gazu. Nafta-Gaz 2014, nr 9, s. 608-616.

[4] Labibzadeh M., Zahabizadeh B., Khajehdezfuly A.: Early-age compressive strength assessment of oil well class $G$ cement due to borehole pressure and temperature changes. Journal of American Science 2010, vol. 6, no. 7, s. 38-45.

[5] McMurry J.: Chemia organiczna. Warszawa, Wydawnictwo Naukowe PWN, 2010.

[6] Raczkowski J., Półchłopek T.: Materiały $i$ środki chemiczne do sporządzania pluczek wiertniczych. Prace IGNiG nr 95, Kraków 1998.

[7] Renpu W.: Advanced Well Completion Engineering. Oxford, Gulf Professional Publishing, 2011.

[8] Uliasz M.: Określenie wpływu płuczek wiertniczych zawierajacych inhibitor polimerowy na jakość zacementowania kolumn rur okładzinowych. Dokumentacja INiG, Kraków 2013.

[9] Uliasz M.: Wpływ polimerów z I-rzędowymi grupami ami- nowymi na właściwości inhibitacyjne płuczki wiertniczej. Nafta-Gaz 2011, nr 1, s. 19-29.

[10] Uliasz M., Chudoba J.: Sole potasowe źródtem jonów $K^{+}$w płuczkach inhibitowanych. Konferencja Naukowo-Techniczna GEOPETROL 2000, Zakopane 25-28 września 2000. Prace IGNiG nr 110.

[11] Uliasz M., Chudoba J., Herman Z.: Ptuczki wiertnicze z inhibitorami polimerowymi i ich oddziatywanie na przewiercane skaty. Prace INiG nr 139, Kraków 2006.

[12] Uliasz M., Herman Z.: Wymagania i właściwości cieczy roboczych. Konferencja z okazji 20-lecia Instytutu Problemów Nafty i Gazu Rosyjskiej Akademii Nauk, Moskwa 24-26 kwietnia 2007, materiały konferencyjne.

[13] Uliasz M., Zima G., Błaż S., Jasiński B.: Systemy płuczek wiertniczych do wiercenia otworów $w$ formacjach tupkowych. Prace Naukowe INiG nr 183 „Rzeczpospolita łupkowa”, Kraków 2012.

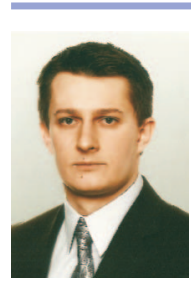

Mgr inż. Bartłomiej JASIŃSKI

Asystent w Zakładzie Technologii Wiercenia.

Instytut Nafty i Gazu - Państwowy Instytut Badawczy ul. Lubicz 25 A

31-503 Kraków

E-mail: bartlomiej.jasinski@inig.pl 